\title{
Determination of Methampyrone Levels Using Thin Layer Chromatography and UV Spectrophotometry Method in Gout Herbal Medicine
}

\author{
Nita Rusdiana ${ }^{1, *}$ Diana Kartika Wulansari ${ }^{2}$ Diana Sylvia ${ }^{3}$
}

\author{
${ }^{1,2.3}$ Muhammadiyah College of Pharmacy in Tangerang, Indonesia \\ ${ }^{*}$ Corresponding author. Email: nita.rusdiana270@gmail.com
}

\begin{abstract}
Based on data from the National Food and Drug Administration, there are 46 withdrawals of herbal products on the market because they contain hazardous chemicals such as MTP, phenylbutazone, dexamethasone, allopurinol, CTM, sildenafil citrate, tadalafil, and paracetamol. MTP is one of the analgesic-antipyretic drugs. However, MTP is widely known to be mixed into rheumatic herbs and gout. The use of high doses of MTP can cause side effects namely, stomach bleeding, palpitations, heart damage, and others. The purpose of this study was to determine the amount of MTP in a gout herbal sample. The sample used in this study was a sample of herbal gout powder sold in herbal stalls in the city of Tangerang. Samples are taken by random sampling method. The MTP qualitative analysis method uses thin layer chromatography. The stationary phase used was silica gel GF 254 while the mobile phase used consisted of methanol : ammonia (100: 1.5). The quantitative analysis method used the UV Spectrophotometry method with a maximum wavelength of $258.5 \mathrm{~nm}$. Qualitative analysis showed that the Rf value of the herbal gout powder samples approached the Rf value of MTP and it was proven by the presence of purple spots under UV light. Furthermore, quantitative analysis showed that the levels of MTP contained in the herbal gout powder sample were $72.59 \pm 1.12$ sample A, 65.34 \pm 1.13 sample B, $11.45 \pm 0.98$ sample C, and 6.70 \pm 0.64 sample D, respectively. The results showed that the herbal gout powder samples were positive contains MTP.
\end{abstract}

Keywords: MTP, TLC, Spectrophotometry UV, Gout Herbal Medicine

\section{INTRODUCTION}

The use of this traditional medicine continues to grow and is widely used around the world during the last few decades. Based on WHO estimates, 65 - $80 \%$ of the world's population uses traditional medicine as the main protection for health [1], [2]. Traditional medicines are ingredients or ingredients in the form of plant ingredients, animal ingredients, mineral substances, galenic preparations or a mixture of these ingredients, which have traditionally been used for treatment based on experience [3]. Herbal medicine is a traditional medicine that is provided traditionally, for example in the form of brewed powder, pills and liquid containing all the plant ingredients that make up the herbal medicine and is used traditionally [4].

Empirical evidence on the use of medicinal plants, the use of medicinal plants as traditional medicines is proven to be relatively safe. Correct use rarely causes side effects, as reflected in the public opinion that traditional medicine is a safe drug without side effects. This opinion is not entirely correct because it can happen that traditional medicine becomes unsafe due to several causes, including mixing with chemicals [5], [6]. Medicinal Chemicals are synthetic compounds or chemical products derived from natural ingredients that are commonly used in modern medicine [7], [8].
Based on the Regulation of the Minister of Health of the Republic of Indonesia No.007 of 2012 in article 7, it has criteria that must be fulfilled by a written traditional medicine that traditional medicines are prohibited from containing, one of which is medicinal chemicals which are the result of isolation or synthetic medicinal properties [3].

According to the findings of the National Agency of Drug and Food Control operation, traditional medicines that are often contaminated with medicinal chemicals are generally traditional medicines used in certain diseases such as rheumatism (Phenylbutazone, MTP, diclofenac, sodium, piroxicam, paracetamol, prednisone, dexamethasone), slimming (Sibutramin hydrochloride), stamina enhancer / strong male drugs (Sildenafil citrate), Diabetes (Glibenclamide), Shortness of breath / asthma (Theophylline) [9].

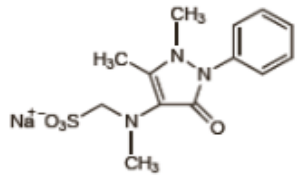

Figure 1 MTP Structure [10]

Medicinal chemical that is often used by doctors as a drug. However, mischievous herbal producers have mixed them 
with herbal medicine to speed healing [11]. The use of uncontrolled doses of MTP can cause side effects and even health problems including gastric bleeding, palpitations, liver damage and others [12]. MTP has analgesic-antipyretic and anti-inflammatory effects. Rogue herbal medicine producers exploit this to increase sales, because consumers like traditional herbal products that react quickly to the body. MTP mixed in herbal medicine is intended to make herbal medicine instantly effective. The content of MTP in herbal medicine is used to treat aches and gout [7], [13].

The results of previous research conducted by Abdul Lathif, in 2013 have conducted research in Surakarta with the title "Analysis of Medicinal Chemicals in Herbal medicine Pegal Linu Sold in Surakarta Using UV Spectrophotometry". Case studies with the object of research on traditional herbal medicine obtained from several herbal medicine shops in Surakarta are as many as 10 samples. The results showed that 2 products contained Diclofenac sodium contained in Herbal medicine G amounted to $41.37 \mathrm{mg} / \mathrm{tab}$ and in Herbal medicine Herbal medicine had levels of $35.65 \mathrm{mg} / \mathrm{tab} .2$ products contain phenylbutazone found in Herbal medicine B $129.79 \mathrm{mg} / \mathrm{tab}$ and Herbal medicine $\mathrm{C}$ has levels of 34.35 $\mathrm{mg} / \mathrm{tab}[14]$.

Seeing the many uses of MTP medicinal chemicals in traditional herbal medicine, this is the reason for the research on "Determination of Methampyrone Levels Using Thin Layer Chromatography Methods and UV Spectrophotometry in Gout Herbal medicine".

\section{RESEARCH METHODOLOGIES}

\subsection{Research Samples}

The sample used in this study was a sample of powdered gout herbal medicine sold in herbal stalls in Periuk District, Tangerang City, taken randomly and simply. Based on the survey results, there were 11 samples of gout herbal medicine in the Periuk District of Tangerang City. The random sampling technique follows the formula $\sqrt{ } n+1$ where $n$ is the number of gout powder herbs.

sample calculation is $=\sqrt{ } 11+1$

$=\sqrt{ } 11+1$

$=3,316+1$

$=4$

From the results of these calculations, the sample will be taken for this study as many as 4 samples.

\subsection{Tools and Materials}

\subsubsection{Tools Required in Research}

The tools used in this study include: Thin Layer Chromatography Plate, UV Spectrophotometry (Hitachi $U$ 2000, Cary 66), scales (Kern), porcelain plates, beaker (Pirex), horn spoon, stirring rod, separating funnel (Pirex). ), filter paper (whattmen), capillary pipette, $254 \mathrm{~nm}$ uv lamp (Camag), $10 \mathrm{ml}$ volumetric flask, volume pipette, erlenmayer, $\mathrm{pH}$ meter (Eutech Instruments), vial bottle, chamber, 2-20 $\mu \mathrm{l}$ micropipette, 20- micropipette $200 \mu \mathrm{l}$, 200-1000 $\mu \mathrm{l}$ micropipette, 1000-5000 $\mu \mathrm{l}$ micropipette, cuvette, centrifuge (kokusan).

\subsubsection{Materials Required in Research}

The materials used in this study are the traditional herbal medicine for gout in the form of powder, which is circulating around Periuk District of Tangerang City, MTP BPFI, NaOH, $0.1 \mathrm{~N} \mathrm{HCl}$, ether, methanol, ammonia, water.

\subsection{Determination of MTP by TLC}

The sample was weighed as much as 2.5 grams dissolved in $50 \mathrm{~mL}$ of water, alkalized with $\mathrm{NaOH}$ to $\mathrm{pH}$, shaken for 30 minutes then filtered. The filtrate was acidified with $0.1 \mathrm{~N}$ $\mathrm{HCl}$ to $\mathrm{pH} \mathrm{1,} \mathrm{then} \mathrm{extracted} \mathrm{with} 25 \mathrm{~mL}$ ether 4 times. The collected ether extract was evaporated to dryness. The remainder of the evaporation is dissolved with $5 \mathrm{~mL}$ of ethanol. The results of this extraction will be used for qualitative analysis.

\subsection{Method Validation}

Validation of the method starts from the preparation of the standard solution of MTP, determination of the maximum wavelength, making the calibration curve for MTP, determining the operating time, precision, accuracy, limit of detection and limit of quantification. Standard methods guidelines use the official AOAC analytical methods. 


\subsection{Determination by Spectrophotometry $U V$}

Weighing the sample powder as much as $240 \mathrm{mg}$ added water up to $10 \mathrm{~mL}$, put it in the centrifuge bottle, shake it until dissolved. After being shaken, enter it into a centrifuge for \pm 10 minutes. The sample will be separated into 2 parts, namely the filtrate and residue, separate the filtrate and residue. The residue was added with $10 \mathrm{~mL}$ of distilled water, shake and filtered (first filtering). The sample will be separated into 2 parts, namely residue and filtrate. $10 \mathrm{~mL}$ of distilled water was added to the residue then shake and filter (second filtering), the resulting filtrate was added with $0.1 \mathrm{~N} \mathrm{HCl}$ as much as $10 \mathrm{~mL}$ of ad. This solution will be used in sample testing.

\subsection{Data Analysis}

The level of the herbal sample is known based on the standard curve equation $y=b x \pm a$, where $y$ is the absorbance value and $x$ is the measured level. From the sample reading, it was found that the absorbance as $\mathrm{y}$ and $\mathrm{x}$ was the measured level with the level of $\mathrm{w} / \mathrm{v}(\mu \mathrm{g} / \mathrm{mL})$.

\section{RESULT AND DISCUSSION}

\subsection{Qualitative Analysis}

After analysing the MTP on 4 samples of gout herbal medicine circulating in Periuk District, Tangerang City. Qualitative analysis was performed using Thin Layer Chromatography with the aim of identifying the presence of MTP in gout herbal medicine. The Thin Layer Chromatography or TLC method was chosen because this method is widely used as an analysis objective, as identification of component separation that can be done with fluorescence colour reagents, or by radiation using ultraviolet light. The standard drug used as a comparison in this study was MTP BPFI.

The identification of MTP in the gout herbal medicine begins with the extraction of a sample of 2.5 grams of the herbal sample dissolved in $50 \mathrm{~mL}$ of water, alkalized with $\mathrm{NaOH}$ to $\mathrm{pH} 9$ with the aim of separating the impurities in the herbal medicine, shaking for \pm 30 minutes then filtering, the filtrate is acidified with $\mathrm{HCl} 0.1 \mathrm{~N}$ to $\mathrm{pH} 1$ with the aim of being able to easily pull the active substance out and separate from the herbal mixture, then extracted with $25 \mathrm{~mL}$ ether 4 times with the intention of gradual or repeated extraction with the aim of increasing the amount of extracted analytes. The evaporation residue is dissolved with $5 \mathrm{~mL}$ ethanol to dissolve the extract.

After extracting the herbal medicine sample, it was followed by qualitative analysis using TLC by selecting the appropriate eluent or mobile phase to elute the TLC plate. The eluent or mobile phase chosen in this study was methanol: ammonia (100: 1.5). Methanol is polar while ammonia is non polar. The eluent was chosen because the standard material for MTP is polar, so it can dissolve in polar solvents. And also the eluent provides a fairly good separation and also a fairly fast elution time. Sprayed with potassium permanganate colour reagent to appear purple spots.

The results of the identification of the sample using methanol: ammonia (100: 1,5) showed that there were purple spots and had the same Rf as the standard. The sample of herbal medicine A has the same Rf value as the standard, namely 0.9 , the sample of herbal medicine B is 0.91 . Then the blotches were viewed on a $254 \mathrm{~nm}$ UV lamp.

Table 1 Analysis of MTP using TLC

\begin{tabular}{c|c|c|c|c|}
\hline Sample & Visualization & $\begin{array}{c}\text { UV } \\
254 \\
\text { nm }\end{array}$ & Rf & Results \\
& & & \\
\hline A & Brownish-yellow & Purple & 0,9 & + \\
B & Brownish-yellow & Purple & 0,91 & + \\
C & Yellow & nd & 0,86 & - \\
D & yellow & nd & 0,84 & - \\
\hline
\end{tabular}

From the table 1 above, it can be seen that the Rf which is the same as the Rf of MTP is found in Herbal medicine A of 0.9 , Herbal medicine B with the Rf value of 0.91 , while the $\mathrm{Rf}$ of Herbal medicine $\mathrm{C}$ is 086 and the lowest $\mathrm{Rf}$ is in Herbal medicine $\mathrm{D}$ which is equal to 0,84 . So it can be concluded that the results of the qualitative analysis of the four samples of herbal medicine A and B were positive for MTP, which was indicated by the presence of purple stains, Herbal medicine $\mathrm{C}$ and D were negative for MTP. Furthermore, the results of the qualitative analysis continued with quantitative analysis using UV spectrophotometry.

\subsection{Analysis Method of Validation}

In this study, to determine the maximum wavelength was carried out using UV spectrophotometry by measuring the absorbance of MTP at ultraviolet wavelengths between 200 $\mathrm{nm}-400 \mathrm{~nm}$, in order to obtain a wavelength of $258.5 \mathrm{~nm}$ at a concentration of $60 \mathrm{ppm}$ which is the optimum concentration because of the peak concentration. it shows good results. The reason for measuring the maximum wavelength is that the change in absorbance for each concentration unit is the greatest at the maximum wavelength, so that the maximum analysis sensitivity will be obtained. 


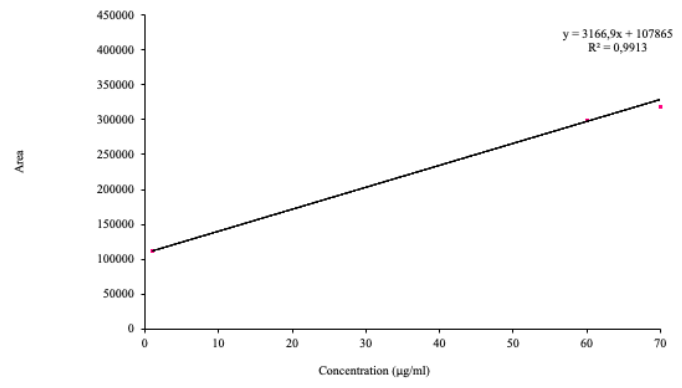

Figure 2 Callibration curve of MTP standard

In making this standard curve, the line equation obtained from the least squares method is used, namely $\mathrm{y}=\mathrm{bx}+\mathrm{a}$, this equation will produce a correlation coefficient (r). The correlation coefficient value that meets the requirements is more than 0.9770 [15]. In this study, the calibration curve was obtained by making a concentration series of $60 \mathrm{ppm}, 70 \mathrm{ppm}$, $80 \mathrm{ppm}, 90 \mathrm{ppm}, 100 \mathrm{ppm}$ from the $1000 \mathrm{ppm}$ standard solution of MTP so that the absorbance results were obtained at the maximum wavelength. The result of the linear regression equation from the obtained calibration curve is $\mathrm{y}=$ $3166.9+107865$ with a correlation coefficient $r^{2}=0.9913$

Table 2 Analysis of MTP using Spectrophotometry UV

\begin{tabular}{c|c|c|} 
Parameter & MTP & $\begin{array}{c}\text { Acceptable } \\
\text { Limits }\end{array}$ \\
\hline Precision (\% RSD) & $0.026 \%$ & $\leq 2 \%$ \\
\cline { 2 - 3 } Accuracy (\%) & $93.612 \%$ & $80-110 \%$ \\
\cline { 2 - 3 } LOD & $1.4684 \mathrm{ppm}$ & - \\
\cline { 2 - 3 } LOQ & $4.8945 \mathrm{ppm}$ & - \\
\hline
\end{tabular}

The method in this research uses the method of adding raw materials. The result of optimization time is up to 5 minutes because the absorbance is relatively constant. Precision is often measured as the percent Relative Standard Deviation (RSD) or Coefficient of Variation (CV). the value of the method precision is $0.026 \%$, so the criteria for precision is accepted because the method provides a CV value of $2 \%$ or less [16]. In the assessment of accuracy, it was carried out by making a $2 \mathrm{~mL}$ concentration solution with 5 repetitions then reading the absorbance before and after the addition of the standard solution concentration of $1000 \mathrm{ppm}$, obtained $93.612 \%$ recovery method. In this study, the LOD value obtained is $1.4684 \mathrm{ppm}$, which means that at this concentration, sample measurements can still be made which gives the results of the accuracy of a tool based on the level of individual accuracy of the analysis results. Meanwhile, the LOQ value was $4.8945 \mathrm{ppm}$, meaning that if the measurement is done, it can still provide accurate analysis.

\subsection{Quantitative Analysis}

Determination of the levels of MTP begins with the extraction of the herbal sample by weighing the sample powder as much as $240 \mathrm{mg}$ added to $10 \mathrm{~mL}$ of distilled water, put it in a shaking centrifuge bottle until dissolved. After being shaken, enter it into a centrifuge for \pm 10 minutes. The reason for using this centrifuge is that heavier particles collect to the bottom of the centrifuge tube because the centrifuge is a means of rotating samples with high speed. The sample will be separated into 2 parts, namely the filtrate and residue, separate the filtrate and residue. The residue is added with distilled water to $10 \mathrm{~mL}$, shake and filter it (first filtering). The sample will be separated into 2 parts, namely residue and filtrate. The residual part was added with water as much as 10 $\mathrm{mL}$ then shake and filter (second filtering), the filtrate resulted from filtering the residue was added with $0.1 \mathrm{~N} \mathrm{HCl}$ to $10 \mathrm{~mL}$. $\mathrm{HCl}$ is added with the intention of removing protein in the sample.

From the results of the extraction, the absorbance readings were carried out on the herbal sample with a maximum absorption rate of $258.5 \mathrm{~nm}$. Then the sample levels of the herbal medicine were calculated. It can be seen from table $\mathbf{3}$, that it can be seen that the highest levels of MTP are found in the herbal medicine code A with a MTP content of $30.24 \%$.

Table 3 Analysis of MTP using Spectrophotometry UV

\begin{tabular}{c|c|c|c|}
\hline Sample & Mean \pm SD & $\%$ & Results \\
\hline A & $72.59 \pm 1.12$ & 30.24 & + \\
\cline { 2 - 4 } B & $65.34 \pm 1.13$ & 27.22 & + \\
\cline { 2 - 4 } C & $11.45 \pm 0.98$ & 4.77 & + \\
\cline { 2 - 4 } D & $6.70 \pm 0.64$ & 2.79 & + \\
\hline
\end{tabular}

The results of the analysis were there were 4 samples of herbal medicine containing the chemical drug MTP with varying levels. Traditional herbal medicine should not contain medicinal chemicals, because herbal medicine is a natural ingredient that can be consumed routinely, if in herbal medicine there are chemical drugs for MTP and consumed regularly it can damage the body's organs.

Based on the hypothesis and the results of the study, 4 samples of the gout herbal medicine tested positive for containing MTP medicinal chemicals.

\section{CONCLUSION}

Based on the results of the analysis of MTP carried out on 4 samples of traditional herbal medicine circulating in Periuk sub-district, Tangerang City, it can be concluded that the results of the qualitative analysis showed that all samples of positive herbal medicine containing MTP were marked as having an Rf that was close to the Rf of MTP which was 0.9 and marked with colour spots. purple under $254 \mathrm{~nm}$ UV light. The results of the quantitative analysis showed that the level of sample A was $30.24 \%$, Sample B was $27.22 \%$, Sample C was $4.77 \%$, Sample D was $2.79 \%$. 


\section{ACKNOWLEDGMENTS}

This work was supported by all the authors, colleagues and Muhammadiyah College of Pharmacy in Tangerang, Indonesia.

\section{REFERENCES}

[1] S. Yee, S. Chu, Y. Xu, and P. Choo, "Regulatory control of Chinese Proprietary Medicines in Singapore," Health Policy (New. York)., vol. 71, pp. 133-149, 2005. doi: 10.1016/j.healthpol.2003.09.013

[2] N. Corp and B. Pendry, "The role of Western herbal medicine in the treatment of gout," Perspect. Med., vol. 3, no. 4, pp. 157-170, 2013. doi: 10.1016/j.hermed.2013.08.002

[3] PMK, "Peratuan Menteri Kesehatan Republik Indonesia Nomor 007 Tahun 2012 tentang Registrasi Obat Tradisional." 2012.

[4] Haidan Yuan, Q. Ma, L. Ye, and G. Piao, "The Traditional Medicine and Modern Medicine from Natural Products," molecules, vol. 21, p. 559, 2016. doi: 10.3390/molecules21050559

[5] L. Ervina and D. Ayubi, "Peran Kepercayaan Terhadap Penggunaan Pengobatan Tradisional Pada Penderita Hipertensi Di Kota Bengkulu," Perilaku dan Promosi Kesehat., vol. 1, no. 1, pp. 1-9, 2018.

[6] L. O. R. K. Sari, "Pemanfaatan Obat Tradisional Dengan Pertimbangan Manfaat dan Keamanannya," Majalah Ilmu Kefarmasian, vol. III, no. 1, pp. 1-7, Apr-2006.

[7] W. M. Sidoretno and I. O. Rz, "Edukasi Bahaya Bahan Kimia Obat Yanga Terdapat didalam Obat Tradisional," J. Pengabdi. Masy., vol. 1, no. 2, pp. 36-42, 2018.

[8] W. Chen, Y. Wu, X. Zhao, S. Liu, F. Song, and Z. Liu, "Screening the anti-gout traditional herbs from TCM using an in vitro method," 2016. doi: 10.1016/j.cclet.2016.05.022

[9] S. Nurrohmah and S. R. Mita, "Review Artikel: Analisis Bahan Kimia Obat (BKO) dalam Jamu Menggunakan Strip Indikator," Farmaka, vol. 15, no. 2, pp. 200-206, 2013.

[10] Martindale, The Complete Drug Reference, 36th ed. London: Pharmaceutical Press, 2009.

[11] BPOM, "Badan pengawas obat dan makanan republik indonesia Nomor 23 Tahun 2019 Tentang Persyaratan Teknis Bahan Kosmetika,” 2019.

[12] Santosa, A. Rumbiana, Z. Wahab, S. P. Kurniawan, R. M. Naibaho, and P. Yogyartono, "Case Report Successful Treatment of Methampyrone-Induced Toxic Epidermal Necrolysis with Therapeutic
Plasma Exchange," Hindawi Case Rep. Med., vol. 2018, p. 4, 2018.

[13] Mei Zhong, "Research Progress of Pathogenesis of Gout and Corresponding Treatment by Chinese Herbs," Adv. Soc. Sci. Educ. Humanit. Res., vol. 196, no. Ssphe 2018, pp. 246-248, 2019.

[14] A. Lathif, "Analisis Bahan Kimia Obat Dalam Jamu Pegal Linu yang Dijual di Surakarta Menggunakan metode Spektrofotometri UV," Surakarta, 2013.

[15] A. Vogel, VOGEL's Textbook of Quantitative Chemical Analysis, vol. 5th. London: Longman Scientific \& Technical, 1989.

[16] AOAC Official Methods of Analysis, "Appendix F : Guidelines for Standard Method Performance Requirements," in Guidelines for Standard Method Performance Requirements, 2016, pp. 1-18. 